\title{
Utilization of vegetable dumplings waste from industrial production by anaerobic digestion**
}

\author{
Agnieszka A. Pilarska ${ }^{1}$, Krzysztof Pilarski ${ }^{2}$, Antoni Ryniecki ${ }^{1}$, Kamila Tomaszyk ${ }^{3}$, \\ Jacek Dach ${ }^{2}$, and Agnieszka Wolna-Maruwka ${ }^{4}$

\begin{abstract}
${ }^{1}$ Institute of Food Technology of Plant Origin, ${ }^{2}$ Institute of Biosystems Engineering, ${ }^{3}$ Department of Mathematical and Statistical Methods, ${ }^{4}$ Department of General and Environmental Microbiology, Poznań University of Life Sciences, Wojska Polskiego 28, 60-637 Poznań, Poland
\end{abstract}

Received June 9, 2016; accepted December 27, 2016

\begin{abstract}
A b s t r a c t. This paper provides the analysis of results of biogas and methane yield for vegetable dumplings waste: dough with fat, vegetable waste, and sludge from the clarifier. Anaerobic digestion of food waste used in the experiments was stable after combining the substrates with a digested pulp composed of maize silage and liquid manure (as inoculum), at suitable ratios. The study was carried out in a laboratory scale using anaerobic batch reactors, at controlled (mesophilic) temperature and $\mathrm{pH}$ conditions. The authors present the chemical reactions accompanying biodegradation of the substrates and indicate the chemical compounds which may lead to acidification during the anaerobic digestion. An anaerobic digestion process carried out with the use of a dough-and-fat mixture provided the highest biogas and methane yields. The following yields were obtained in terms of fresh matter: $242.89 \mathrm{~m}^{3} \mathrm{Mg}^{-1}$ for methane and $384.38 \mathrm{~m}^{3} \mathrm{Mg}^{-1}$ for biogas, and in terms of volatile solids: $450.73 \mathrm{~m}^{3} \mathrm{Mg}^{-1}$ for methane and $742.40 \mathrm{~m}^{3} \mathrm{Mg}^{-1}$ for biogas. Vegetables and sludge from the clarifier (as fresh matter) provided much lower yields.

$\mathrm{K}$ e y w o r d s: dumpling wastes, anaerobic digestion, biodegradation pathways, biogas and methane yield
\end{abstract}

\section{INTRODUCTION}

Large amounts of food waste (FW) cause severe environmental pollution when discharged without control. Conventional approaches to the disposal of FW include landfilling, incineration and aerobic composting (Pilarski and Pilarska 2009; Waszkielis et al., 2013). Food waste is also disposed of by anaerobic digestion, which is a promising method (Zeshan et al., 2015). Food waste is a suitable organic substrate which is readily biodegradable due to

\footnotetext{
*Corresponding author e-mail: pilarska@up.poznan.pl

** This work was supported by research grant NCN no. N N313 432539: Assessment of the fertilizer value and impact on the soil of after digest pulpy originating from the process of biogas production, with application of different organic substrates, 2010-2013.
}

its high water content (70-80\%), therefore, it can successfully be digested in anaerobic conditions to obtain biogas (Kondusamy and Kalamdhad, 2014).

Anaerobic digestion (AD) consists of a number of biochemical reactions, catalysed by several microbial species which require anaerobic conditions to survive. How much biogas is generated and whether the AD process is stable depends on the type and volume of waste supplied into the digester (Zhang et al., 2014). It also depends on certain key parameters, such as temperature, volatile fatty acids (VFAs), pH, ammonia, organic loading rate (OLR), carbon/nitrogen ratio, nutrients and trace elements, and other things (Chen et al., 2015; Grimberg et al., 2015; Jabeen et al., 2015; Montanés et al., 2014). For long-term operation of $\mathrm{AD}$, it is vital to maintain the key parameters within the appropriate range. Anaerobic digestion of organic matter is generally divided into the following steps: hydrolysis, acidogenesis, acetogenesis and methanogenesis (Appels et al., 2011). In the first step, high molecular materials are decomposed to form molecular materials (eg fatty acids, amino acids). It is followed by acidogenesis, where less complex molecular organic material is degraded to form volatile fatty acids and the gases $\mathrm{NH}_{3}, \mathrm{CO}_{2}, \mathrm{H}_{2} \mathrm{~S}$. In the acetogenesis step, the organic products formed in the second step are fermented to form acetate, $\mathrm{H}_{2}, \mathrm{CO}_{2}$, and these products are converted to methane in the methanogenesis step. As a rule, the substrates that are useful in methanogenesis include short-chained fatty acids, n-alcohols, and i-alcohols, and gas:

(C) 2017 Institute of Agrophysics, Polish Academy of Sciences 
$\mathrm{CO}_{2}, \mathrm{O}_{2}, \mathrm{H}_{2}$ (Deublein and Steinhauser, 2011). Apples et al. (2011) report that methane is produced by two groups of methanogens, one of which uses the acetate as a nutrient, and the other does $\mathrm{H}_{2}$ and $\mathrm{CO}_{2}$.

Even though anaerobic digestion of food waste may be considered as a proven disposal method, it remains to be somewhat difficult to carry out; these difficulties are the subject of scientific investigations. In addition to the strict control of its key parameters referred to above, problems in $\mathrm{AD}$ are potentially caused by inhibition. The reasons for inhibition in the case of anaerobic digestion of food waste may be different. One of the reasons is unbalanced nutrients: while trace elements $\mathrm{Zn}, \mathrm{Fe}$, Mo etc., are sufficient, the content of macroelements $\mathrm{Na}, \mathrm{K}$, etc. - for instance in molasses - is too high (Chen et al., 2008; Fang et al., 2011), and the $\mathrm{C}: \mathrm{N}$ ratio is different from the optimum reported in literature (Parkin and Owen, 1986; Pilarska et al., 2014). Moreover, lipids concentration of FW is always higher than the limit concentration, which inhibits the process as well and limits biogas yield (Silvestre et al., 2014). These problems can be counteracted by co-fermenting food waste with other organic waste, such as sewage sludge (Silvestre et al., 2014), swine and dairy manure (Kavacik and Topaloglu, 2010), rice straw (Zhan-Jiang et al., 2014), rice husk (Zeshan et al., 2015), cattle slurry (Comino et al., 2012), kitchen wastewater (Tawik and El-Qelish, 2012). Their addition provides higher buffer capacity (reducing ammonia concentration), improves the content of nutrients, reduces high concentrations of $\mathrm{K}^{+}, \mathrm{Na}^{+}$(dilution with cow manure), and facilitates biodegradation of lipids, leading eventually to improved methane yields. The material typically used in studies consists of food waste from restaurants or university cafeterias (Razaviarani et al., 2013; Zeshan et al., 2015). There have been reports on experiments carried out with the use of industrial waste, such as sugar beet pulp (Montanés et al., 2014), molasses (Fang et al., 2011), cheese whey (Comino et al., 2012), coffee waste (Neves et al., 2006), fat (Silvestre et al., 2014), fruit and vegetable waste (VW) (Di Maria et al., 2015).

This paper is intended to analyse the biogas and methane yield of waste originating from the production of vegetable dumplings (VDW). The inoculum in these experiments was a digested mixture of maize silage and liquid manure. The studies were carried out in a laboratory scale using anaerobic batch reactors, at controlled (meso- philic) temperature and $\mathrm{pH}$ conditions. The presented, in this work, chemical reactions accompanying biodegradation of the substrates may be a useful tool for performing appropriate biochemical analyses and for the mathematical modelling of anaerobic digestion.

\section{MATERIALS AND METHODS}

The inoculum (digestion pulp) was obtained from an agricultural biogas plant, fed with maize silage and liquid manure. The vegetable dumplings waste (VDW): dough (DH), fat (FT), vegetable waste (VW) composed of carrot, parsley, champignons, cabbage, pepper, onion, celeriac, garlic, and sludge from the clarifier (SC), were provided by a manufacturer of farinaceous products, including dumplings, located in north Poland.

In the experiment three samples were tested: doughand-fat $(\mathrm{DH}+\mathrm{FT})$, vegetable waste $(\mathrm{VW})$, sludge from the clarifier (SC), mixed with the inoculum. The share of dough-and-fat in digestion mixture $\mathrm{DH}+\mathrm{FT}$ was $4.2 \%$ (in the ratio $90 \%$ plus $10 \%$, respectively), in digestion mixture VW was $12.5 \%$ of vegetable waste, while in the digestion mixture SC $-25 \%$ of sludge from the clarifier. The doughand-fat component was a mixture of the two components $(\mathrm{DH}+\mathrm{FT})$ for technological reasons (as waste, the two materials are typically combined).

Based on the VDI 4630 guideline, the present authors attempted to keep the total solids content (TS) of the batch at less than $10 \%$ to guarantee adequate mass transfers and content of volatile solids (VS) in the batch from inoculum - between 1.5 and $2 \%$. The $\mathrm{pH}$ of the mixtures before digestion was in the range of 6.8-7.5.

Table 1 shows the mixture compositions and some of their parameters.

Biogas production rates as well as biogas and methane yield analyses were carried out in accordance with the German standard DIN 38 414-S8: Fermentation of organic materials - Characterisation of the substrate, sampling, collection of material data, fermentation tests (Beuth Verlag $\mathrm{GmbH}$, Berlin 1895). The anaerobic digestion process was performed using a multichamber biofermenter (Fig. 1).

In this experiment, twelve $1.4 \mathrm{dm}^{3}$ biofermenters were used in the tests. Each biofermenter was filled with $1 \mathrm{dm}^{3}$ of a starting material composed of suitable substrate mixtures. The samples (substrate/inoculum) and the inoculum (also referred to as control) were digested in 3 repetitions.

T a b l e 1. Substrate/inoculum ratios and selected parameters (mean values, with standard deviation in parenthesis)

\begin{tabular}{|c|c|c|c|c|c|c|c|c|c|c|}
\hline \multirow{2}{*}{$\begin{array}{l}\text { Sample } \\
\text { DH+FT }\end{array}$} & \multicolumn{2}{|c|}{ Substrate (g) } & \multicolumn{2}{|c|}{ Inoculum (g) } & \multicolumn{2}{|c|}{ Mixtures $\mathrm{pH}$} & \multicolumn{2}{|c|}{ Mixtures C:N ratio } & \multicolumn{2}{|c|}{ Mixtures TS (\%) } \\
\hline & 50.00 & $(0.05)$ & 1150.35 & $(0.26)$ & 7.62 & $(0.06)$ & 28.00 & (2.65) & 4.84 & $(0.05)$ \\
\hline VW & 150.66 & $(0.28)$ & 1050.63 & $(0.55)$ & 7.59 & $(0.11)$ & 27.67 & (2.08) & 3.67 & $(0.06)$ \\
\hline $\mathrm{SC}$ & 301.45 & $(0.82)$ & 901.53 & $(0.95)$ & 6.90 & $(0.08)$ & 32.00 & $(2.65)$ & 6.18 & $(0.07)$ \\
\hline
\end{tabular}

$\mathrm{DH}+\mathrm{FT}$ - dough with fat, VW - vegetable waste, $\mathrm{SC}$ - sludge from clarifier. 


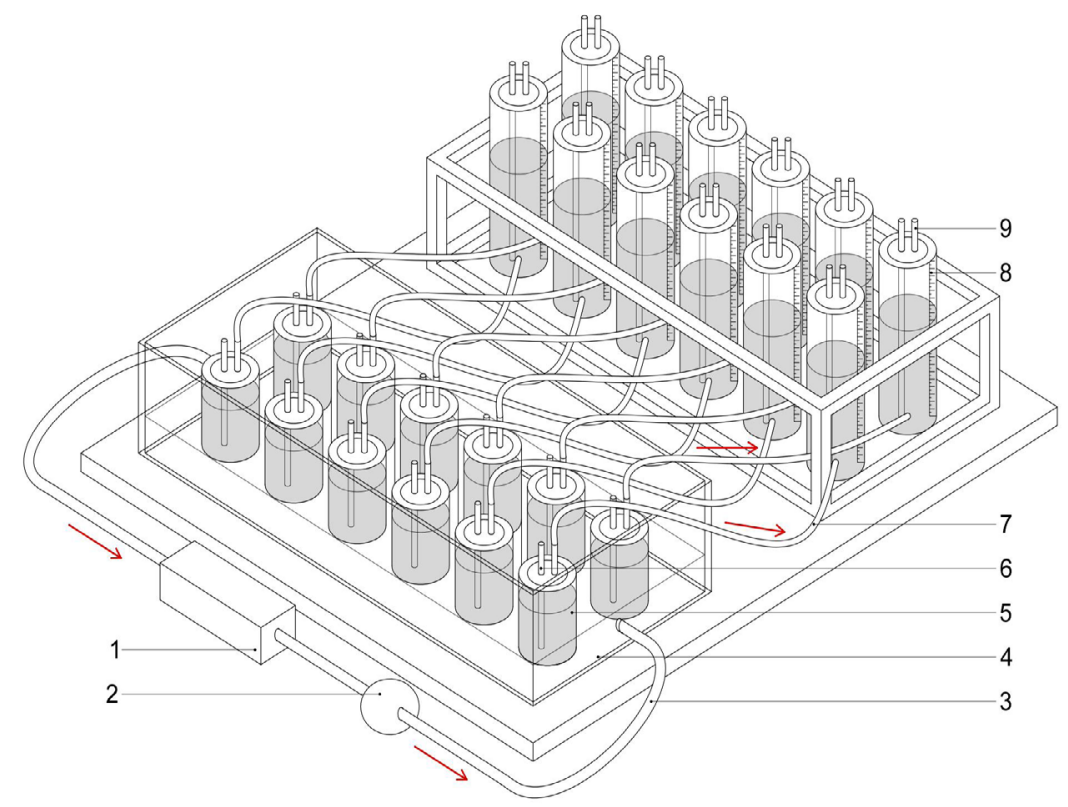

Fig. 1. Biofermenter for biogas production tests (12-chamber section): 1 - water heater with temperature adjustment; 2 - water pump; 3 - insulated tubes for liquid heating medium; 4 - water jacket $\left(39^{\circ} \mathrm{C}\right) ; 5$ - biofermenter $\left(1.4 \mathrm{dm}^{3}\right) ; 6$ - slurry-sample drawing tube; 7 - tube for transporting the biogas formed; 8 - graduated tank for biogas; 9 - gas sampling valve.

The material was stirred once in $24 \mathrm{~h}$. The biofermenters were equipped with a water jacket (3) connected to a heater (1) to control the temperature and carry out the process in a desirable temperature range. The test was carried out in mesophilic temperature conditions (at approx. $39^{\circ} \mathrm{C}$ ). The biogas produced was transported via tube (6) into tanks (7) filled with an acidic liquid. In accordance with the VDI 4630 guidelines, the experiment was continued for each substrate until the daily biogas production was below $1 \%$ of its total generated amount.

The substrates and inoculum were analysed according to Polish standards or procedures: dry matter/humidity (drier method PN-75 C-04616/01), organic matter and ash (incineration according to the modified standard PN-Z15011-3), $\mathrm{pH}$ (potentiometric method PN-90/A-75101.06), conductivity (potentiometric method PN-EN 27888:1999).

The following analyses were also carried out: total nitrogen - Kjeldahl method, total organic carbon - Tiurin method, total P - spectrophotometric method, alkalinity potentiometric titration method, COD - titration method, as well as macroelements - atomic absorption spectrometry method (AAS). The substrates used in this study and the control were analysed in 3 repetitions.

The gas volumes generated were measured once a day. Qualitative analyses were carried out for gas volumes of $1 \mathrm{dm}^{3}$ or more, initially once a day, then - as lower volumes were generated - every third day.

After the quantitative and qualitative analyses of the gas obtained, the final step is to assess the biogas yield per unit $\left(\mathrm{m}^{3} \mathrm{Mg}^{-1}\right)$ of organic dry matter. The calculations are based on the test results. The biogas yield for the substrates is calculated by subtracting the gas volume generated for the inoculum. For the batches in the reactors filled with the substrate mixtures or for the reference substrates, the ratio of gas generated from the seeding sludge in the test is calculated from the following equation:

$$
V_{I S(\text { corr. })}=\frac{\Sigma V_{I S} m_{I S}}{m_{M}}
$$

where: $V_{I S(c o r r .)}-$ volume of gas released from the seeding sludge $\left(\mathrm{ml}_{\mathrm{N}}\right), \Sigma V_{I S}-$ total gas volume in the test performed on seeding sludge for the given test duration $\left(\mathrm{ml}_{\mathrm{N}}\right), m_{I S}-$ mass of the seeding sludge used for the mixture $(\mathrm{g})$, and $m_{M}$ - mass of the seeding sludge used in the control test (g).

The specific digestion gas production $\left(V_{S}\right)$ from the substrate or reference substrate $v s$. test duration, is calculated step by step from reading to reading in accordance with the equation:

$$
V_{S}=\frac{\Sigma V_{n} 10^{4}}{m w_{T} w_{v}},
$$

where: $V_{S}-$ specific digestion gas production relative to the ignition loss mass during the test period $\left(1_{\mathrm{N}} \mathrm{kg} \mathrm{GV}^{-1}\right)$, $\Sigma V_{\mathrm{n}}$ - net gas volume of the substrate or reference substrate for the given test time $\left(\mathrm{ml}_{\mathrm{N}}\right), m$ - mass of the weighed-in substrate or reference substrate $(\mathrm{g}), w_{T}$ - dry residue of the sample or of the reference sludge (\%), and $w_{V}$ - loss on ignition $(\mathrm{GV})$ of dry matter of the sample or of the reference sludge (\%).

One-way ANOVA (Analysis of variance) was applied to compare the means for the cumulative biogas yield, cumulative methane yield and the percentage of methane 
T a b l e 2. Cumulative methane and biogas yield from $\mathrm{Mg}$ of fresh matter, dry matter and dry organic matter, and percentage content of methane - for individual substrates (mean values, with standard deviation in parenthesis)

\begin{tabular}{|c|c|c|c|c|c|c|c|}
\hline \multirow{3}{*}{ Sample } & \multicolumn{2}{|c|}{ Fresh matter } & \multicolumn{2}{|c|}{ Total solids } & \multicolumn{2}{|c|}{ Volatile solids } & \multirow{3}{*}{$\mathrm{CH}_{4}(\%)$} \\
\hline & Methane & Biogas & Methane & Biogas & Methane & Biogas & \\
\hline & \multicolumn{2}{|c|}{$\left(\mathrm{m}^{3} \mathrm{Mg}^{-1} \mathrm{FM}\right)$} & \multicolumn{2}{|c|}{$\left(\mathrm{m}^{3} \mathrm{Mg}^{-1} \mathrm{TS}\right)$} & \multicolumn{2}{|c|}{$\left(\mathrm{m}^{3} \mathrm{Mg}^{-1} \mathrm{VS}\right)$} & \\
\hline $\mathrm{DH}+\mathrm{FT}$ & $\begin{array}{l}242.89 \\
(9.56) \mathrm{c}\end{array}$ & $\begin{array}{c}384.38 \\
(8.97) \mathrm{c}\end{array}$ & $\begin{array}{c}412.21 \\
(17.46) b\end{array}$ & $\begin{array}{c}747.80 \\
(16.02) \mathrm{c}\end{array}$ & $\begin{array}{c}450.73 \\
(17.00) b\end{array}$ & $\begin{array}{c}742.40 \\
(15.24) \mathrm{c}\end{array}$ & $\begin{array}{c}55.11 \\
(1.21) b\end{array}$ \\
\hline VW & $\begin{array}{c}28.72 \\
(1.16) \mathrm{a}\end{array}$ & $\begin{array}{c}53.43 \\
(1.8) \mathrm{a}\end{array}$ & $\begin{array}{c}318.99 \\
(12.83) \mathrm{a}\end{array}$ & $\begin{array}{c}593.40 \\
(18.86) \mathrm{a}\end{array}$ & $\begin{array}{c}340.34 \\
(12.42) \mathrm{a}\end{array}$ & $\begin{array}{c}583.15 \\
(17.89) \mathrm{a}\end{array}$ & $\begin{array}{c}53.75 \\
(0.55) b\end{array}$ \\
\hline $\mathrm{SC}$ & $\begin{array}{c}61.19 \\
(0.93) \mathrm{b}\end{array}$ & $\begin{array}{c}105.25 \\
(0.97) \mathrm{b}\end{array}$ & $\begin{array}{l}319.85 \\
(5.65) \mathrm{a}\end{array}$ & $\begin{array}{c}657.55 \\
(4.11) \mathrm{b}\end{array}$ & $\begin{array}{c}335.83 \\
(5.35) \mathrm{a}\end{array}$ & $\begin{array}{c}700.00 \\
(3.36) \mathrm{b}\end{array}$ & $\begin{array}{c}48.64 \\
(0.56) \mathrm{a}\end{array}$ \\
\hline $\begin{array}{l}\text { ANOVA } \\
\text { (p value) }\end{array}$ & $<0.0001$ & $<0.0001$ & 0.0002 & $<0.0001$ & 0.0003 & 0.0001 & 0.0002 \\
\hline
\end{tabular}

Explanations as in Table 1. Means within a column with different letters are significantly different $(\mathrm{p}<0.05)$.

in the biogas, obtained for the substrate/inoculum mixtures (Table 2). Pair-wise comparisons of the means were carried out, where appropriate, using Tukey honest significant difference tests (Cochran and Cox, 1992). The biogas and methane volumes obtained in the test were expressed per $\mathrm{Mg}$ of fresh matter, dry matter, and dry organic matter, therefore, statistical analysis was performed on the three data sets, obtained from the conversion data.

All statistical analyses were carried out using the STATISTICA 10 software.

\section{RESULTS AND DISCUSSION}

The chemical characterisation of the vegetable dumplings waste (VDW) provided values (Table 3 ) which are in agreement with those reported by other authors (Silvestre et al., 2014; Zuo et al., 2015). The information relates to fat and vegetables which have been tested before in anaerobic digestion (no reports on the anaerobic digestion of dough were found). Among the test substrates, vegetables waste (VW) has the lowest percentage of total solids (TS) and high water content, roughly $90 \%$ (Siddiqui, 1989). The highest TS $(95.18 \%)$ is reported for fat (FT), then for dough (DH, 49.13\%), and for sludge from the clarifier (SC, 16\%). The sludge from the clarifier is a suspension comprising fat, flour and water. While the content of volatile solids (VS) for the substrates is high and comparable, the value of VS for the materials is affected by their chemical composition. Fat is an ester of glycerol and fatty acids, mainly triacylglycerols (Clayden et al., 2001). The dough for dumplings is mainly composed of wheat flour (ground cereal grains) combined with water (Yan et al., 2001). Chemically speaking, it is: digestible carbohydrates (starch, 60-70\%); water (14-15\%); proteins (9-14\%); and a small amount of fat, ash, crude fibre, minerals (Beck and Ziegler, 1989; Belitz et al., 2009; Brown et al., 1996). Vegetables are composed mainly of starch, fibre and further proteins and fat (small and trace amounts), in addition to water (Siddiqui, 1989).

The carbon content indicates that the highest calorific value is that of the fat $(66.80 \% \mathrm{TS})$, and the lowest is that of the vegetables $(23.20 \% \mathrm{TS})$. The parameters of the substrates discussed above are correlated with the findings for biogas and biomethane yields (Table 2). With the exception of the inoculum $(\mathrm{pH}=7.47)$, the substrates have $\mathrm{pH}$ values in the acidic range (from 3.35 to 5.35), which is in agreement with other reports (Di Maria et al., 2015; Silvestre et al., 2014). Such pH values are caused by the presence of appropriate chemical compounds (organic acids, vitamins), as well as additives used in industrial food production processes (for instance, texture improvers). Low $\mathrm{pH}$ values are known to inhibit anaerobic digestion. Combining the substrates with fermented liquid manure and maize silage resulted in a buffering system which provided stable methane production in anaerobic conditions. The ratio of the mixtures and their key parameters are shown in Table 1.

The essential building materials of the substrates tested by the authors are carbohydrates, including starch and fibre, in addition to fat which is an independent substrate, and a small percentage of protein which is present in flour (grains) and vegetables (Belitz et al., 2009). When discussing the biodegradation of farinaceous waste, these compounds are essential. Starch has two structural components: amylose and amylopectin (Beck and Ziegler, 1989). Amylose forms long, straight glucose chains, while amylopectin is built of a chain composed of glucosyl radicals. Also cellulose and hemicellulose - originally referred to as crude fibre - are built of glucose (Brown et al., 1996; Molinuevo-Salces et al., 2013). The molecular formula of starch, cellulose and hemicellulose is $\left(\mathrm{C}_{6} \mathrm{H}_{10} \mathrm{O}_{5}\right)_{\mathrm{n}}$. 
T a b l e 3. Parameters of the substrates and inoculum used for the studies (mean values, with standard deviation in parenthesis)

\begin{tabular}{|c|c|c|c|c|c|c|c|c|c|c|}
\hline \multirow{2}{*}{$\begin{array}{l}\text { Indicator } \\
\text { TS (\%) }\end{array}$} & \multicolumn{2}{|c|}{ Inoculum } & \multicolumn{2}{|c|}{ DH } & \multicolumn{2}{|c|}{ FT } & \multicolumn{2}{|c|}{ VW } & \multicolumn{2}{|c|}{$\mathrm{SC}$} \\
\hline & 2.91 & $(0.06)$ & 49.13 & $(0.29)$ & 95.18 & $(0.32)$ & 9.00 & $(0.10)$ & 16.00 & $(0.11)$ \\
\hline VS (\% TS) & 71.64 & $(0.24)$ & 98.55 & $(0.11)$ & 99.92 & $(0.03)$ & 93.77 & $(0.26)$ & 98.13 & $(0.26)$ \\
\hline $\mathrm{pH}$ & 7.47 & $(0.07)$ & 4.05 & $(0.07)$ & 5.35 & $(0.07)$ & 4.45 & $(0.08)$ & 3.35 & $(0.07)$ \\
\hline $\begin{array}{l}\text { Conductivity } \\
\left(\mathrm{mS} \mathrm{cm}^{-1}\right)\end{array}$ & 10.98 & $(0.12)$ & 0.68 & $(0.07)$ & 15.24 & $(0.12)$ & 0.36 & $(0.04)$ & 1.74 & $(0.10)$ \\
\hline $\mathrm{C} / \mathrm{N}$ ratio & 27.33 & $(2.31)$ & 38.00 & $(3.61)$ & 73.00 & $(3.00)$ & 28.33 & $(2.52)$ & 46.00 & $(3.00)$ \\
\hline $\mathrm{C}(\% \mathrm{TS})$ & 31.74 & $(0.50)$ & 41.67 & $(0.45)$ & 66.80 & $(0.56)$ & 23.20 & $(0.30)$ & 45.60 & $(0.86)$ \\
\hline $\mathrm{N}(\% \mathrm{TS})$ & 1.17 & $(0.09)$ & 1.10 & $(0.09)$ & 0.91 & $(0.03)$ & 0.82 & $(0.07)$ & 0.99 & $(0.07)$ \\
\hline $\mathrm{N}-\mathrm{NH}_{4}^{+}(\% \mathrm{TS})$ & 0.70 & $(0.05)$ & 0.53 & $(0.03)$ & 0.46 & $(0.03)$ & 0.60 & $(0.06)$ & 0.76 & $(0.06)$ \\
\hline $\begin{array}{l}\text { Alkalinity } \\
\left(\mathrm{mg} \mathrm{CaCO}_{3} \mathrm{dm}^{-3}\right)\end{array}$ & 419.67 & (35.13) & 309.67 & $(9.71)$ & 422.67 & (10.69) & 260.33 & $(9.29)$ & 612.00 & (13.00) \\
\hline $\mathrm{COD}\left(\mathrm{mg} \mathrm{dm}^{-3}\right)$ & 815.33 & $(35.73)$ & 1343.00 & $(46.03)$ & 2057.33 & (46.09) & 943.33 & $(42.50)$ & 2804.67 & (78.93) \\
\hline \multicolumn{11}{|c|}{ Macroelements (mg kg$\left.{ }^{-1} \mathrm{TS}\right)$} \\
\hline K & 124.67 & $(9.29)$ & 152.67 & (12.01) & 180.67 & $(5.86)$ & 90.33 & $(6.03)$ & 122.67 & (4.16) \\
\hline $\mathrm{Na}$ & 75.67 & $(5.03)$ & 60.33 & $(4.04)$ & 85.33 & $(6.51)$ & 82.00 & $(3.61)$ & 88.67 & $(3.51)$ \\
\hline $\mathrm{Ca}$ & 2.76 & $(0.16)$ & 3.09 & $(0.08)$ & 2.92 & $(0.04)$ & 1.71 & $(0.05)$ & 2.34 & $(0.11)$ \\
\hline $\mathrm{Mg}$ & 0.76 & $(0.07)$ & 0.92 & $(0.03)$ & 1.16 & $(0.05)$ & 1.15 & $(0.05)$ & 1.05 & $(0.07)$ \\
\hline
\end{tabular}

Explanation as in Table 1.

The present authors have proposed the possible path ways of the biodegradation of the above-mentioned polysaccharides, in the form of chemical Eqs (3)-(7). The equations illustrate the probable conversions of chemical compounds in the consecutive phases of anaerobic digestion.

Hydrolysis

$\left(\mathrm{C}_{6} \mathrm{H}_{10} \mathrm{O}_{5}\right)_{\mathrm{n}}+\mathrm{H}_{2} \mathrm{O} \rightarrow \mathrm{nC}_{6} \mathrm{H}_{12} \mathrm{O}_{6}$,

Acidogenic phase

$\mathrm{C}_{6} \mathrm{H}_{12} \mathrm{O}_{6}+2 \mathrm{H}_{2} \mathrm{O} \rightarrow 2 \mathrm{CH}_{3} \mathrm{COOH}+2 \mathrm{CO}_{2}+4 \mathrm{H}_{2}$,

$\mathrm{C}_{6} \mathrm{H}_{12} \mathrm{O}_{6} \rightarrow 2 \mathrm{C}_{2} \mathrm{H}_{5} \mathrm{OH}+2 \mathrm{CO}_{2}$,

Acetogenic phase

$\mathrm{C}_{2} \mathrm{H}_{5} \mathrm{OH}+\mathrm{H}_{2} \mathrm{O} \rightarrow \mathrm{CH}_{3} \mathrm{COOH}+2 \mathrm{H}_{2}$,

Methanogenic phase

$\mathrm{CH}_{3} \mathrm{COOH} \rightarrow \mathrm{CH}_{4}+\mathrm{CO}_{2}$.

In the first phase (hydrolysis) the polysaccharides decompose to form monosaccharide glucose (3), (Beck and Ziegler, 1989). Glucose may further decompose, as shown in Eqs (4)-(6), in the acidogenic and acedogenic phases to form ethanoic acid (Eqs (4), (6)) ethyl alcohol (Eq. (5)).
The ethanoic acid is used by methanogens forming the gas mixture $\mathrm{CH}_{4}+\mathrm{CO}_{2}$ in the final phase (Eq. (7)), (Appels et al., 2011).

In the present study, fat was found to have a significant effect on methane yield for the sample of dough with fat $(\mathrm{DH}+\mathrm{FT})$ and the sample of sludge from the clarifier. Therefore, the intermediates of its decomposition would be worth investigating. In the hydrolysis phase, the fats (triglyceride carboxylic acids) decompose into glycerine and higher carboxylic acids - the building material of fats (Yan et al., 2001). The fat used for the dumplings was of animal origin. Considering its biodegradation, the authors assumed the example of stearic acid triglyceride which has the highest share in animal fat.

In theory, decomposition of glycerine, $\mathrm{C}_{3} \mathrm{H}_{8} \mathrm{O}_{3}$, leads

(6) to intermediate products - glyceric aldehyde, $\mathrm{C}_{3} \mathrm{H}_{6} \mathrm{O}_{3}$, and dihydroxyacetone, $\mathrm{C}_{3} \mathrm{H}_{6} \mathrm{O}_{3}$ (Eq. (8)) (Clayden et al., 2001; Lui and Greeley, 2011). Glyceric aldehyde provides such compounds as methyl aldehyde, methanoic acid and methyl alcohol in the acidogenic phase, as shown by reaction (Eq. (9)). Dihydroxyacetone (DHA), a sugar having three carbon atoms, is stable in the $\mathrm{pH}$ range from Eqs (4) to (6). Above that range, DHA is decomposed into methyl alcohol (Eq. (10)). A number of studies reported recently addressed 
the problem of decrease in the $\mathrm{pH}$ after the initial phase of anaerobic digestion of glycerin (Nghiem et al., 2014). The present authors believe that the $\mathrm{pH}$ tended to drop due to the formation of glyceric aldehyde and dihydroxyacetone (Eq. (8)) as well as products of their further decomposition (Eqs (9), (10)).

$$
\begin{aligned}
& 2 \mathrm{CH}_{2}(\mathrm{OH}) \mathrm{CH}(\mathrm{OH}) \mathrm{CH}_{2}(\mathrm{OH}) \rightarrow \mathrm{CH}_{2}(\mathrm{OH}) \mathrm{CH}(\mathrm{OH}) \\
& \mathrm{CHO}+\mathrm{CH}_{2}(\mathrm{OH}) \mathrm{COCH}_{2}(\mathrm{OH})+2 \mathrm{H}_{2},
\end{aligned}
$$

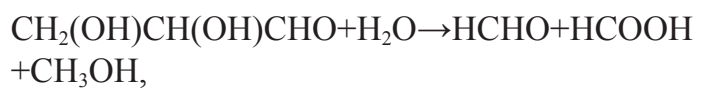

In fact, biodegradation of stearic acid triglyceride, a compound composed of numerous carbon and hydrogen atoms, may proceed in a number of ways. The 'cutting' of the hydrocarbon chain by bacteria in the acidogenic phase may lead to such compounds as ethyl alcohol, 2-oxopropanoic acid, 2-hydroxypropanoic acid, 1,4-butanedioic acid, methyl alcohol, propan-2-one, mathanoic acid (Clayden et al., 2001). Accumulation of volatile fatty acids formed in this phase of anaerobic digestion (among which propionic acid is frequently indicated) inhibits the process (Silvestre et al., 2011; 2014). It might be useful to add the chemical compounds indicated above to the investigations that have been performed so far.

Although proteins have a positively lower share in the organic waste used in this work, their biodegradation is also worth attention, if only for their complex structure. Proteins are biopolymers composed of at least 100 amino acids. Amino acid radicals are connected with one another by peptide bonds -CONH- forming long chains (Clayden et al., 2001; Creighton, 1992). Proteins comprise essentially $\mathrm{C}, \mathrm{O}, \mathrm{H}, \mathrm{N}, \mathrm{S}$, but also $\mathrm{P}$ and sometimes cations of the metals $\mathrm{Mg}^{2+}, \mathrm{Fe}^{2+}, \mathrm{Cu}^{2+}$ as well as other ones. Their composition is different from that of amino acids because most proteins have other types of molecules attached to the amino acid radicals - typically sugars or organic compounds. To simplify the chemical reactions (Eqs (11)-(14)) illustrating the degradation of the complex compound, the present authors used the form: n-protein-C- $\mathrm{NH}_{2} \mathrm{SP}$ (Pilarska et al., 2016).

Hydrolysis

$\mathrm{n}-$ protein $-\mathrm{C}-\mathrm{NH}_{2}+\mathrm{H}_{2} \mathrm{O} \rightarrow \mathrm{C}_{\mathrm{x}} \mathrm{H}_{\mathrm{y}} \mathrm{O}_{\mathrm{z}} \mathrm{N}_{\mathrm{a}} \mathrm{S}_{\mathrm{b}}+\mathrm{cP}$,

Acidogenic phase

$$
2 \mathrm{C}_{\mathrm{x}} \mathrm{H}_{\mathrm{y}} \mathrm{O}_{\mathrm{z}} \mathrm{N}_{\mathrm{a}} \mathrm{S}_{\mathrm{b}}+5 \mathrm{H}_{2} \mathrm{O} \rightarrow 2 \mathrm{C}_{\mathrm{x}} \mathrm{H}_{\mathrm{y}} \mathrm{O}_{\mathrm{z}}+2 \mathrm{aNH}_{3}+2 \mathrm{bH}_{2} \mathrm{~S},
$$

Acetogenic phase

$$
\mathrm{C}_{\mathrm{x}} \mathrm{H}_{\mathrm{y}} \mathrm{O}_{\mathrm{z}}+\mathrm{H}_{2} \mathrm{O} \rightarrow \mathrm{xCH} \mathrm{CH}_{3} \mathrm{COOH}+\mathrm{H}_{2} \text {, }
$$

Methanogenic phase

$$
\mathrm{xCH}_{3} \mathrm{COOH} \rightarrow \mathrm{x} / 2 \mathrm{CH}_{4}+\mathrm{x} / 2 \mathrm{CO}_{2} \text {. }
$$

Hydrolysis leads to the degradation of the biopolymer to amino acids $\left(\mathrm{C}_{\mathrm{x}} \mathrm{H}_{\mathrm{y}} \mathrm{O}_{\mathrm{z}} \mathrm{N}_{\mathrm{a}} \mathrm{S}_{\mathrm{b}}\right)$ and phosphate radicals P (11) (Clayden et al., 2001; Pilarska et al., 2016). In the acidogenic phase, the amino acids decompose to form less complex organic compounds - as in the degradation of the biopolymers described before (carbohydrates and fat), as well as $\mathrm{NH}_{3}$ and $\mathrm{H}_{2} \mathrm{~S}$ (Eq. (2)). Ammonia and hydrogen sulphide, although generally known to inhibit anaerobic digestion (Chen et al., 2008), tend not to destabilise the process in the case of the materials used in these experiments. Ultimately, decomposition of ethanoic acid resulting from the acedogenic phase leads to $\mathrm{CH}_{4}$ and $\mathrm{CO}_{2}$.

Knowledge of the intermediate products of degradation of organic materials, used as substrates in biogas plants, is very useful in the optimisation of anaerobic digestion to improve its efficiency. It provides information on the potential methane yield resulting from the process stoichiometry (amount of carbon and hydrogen) as well as on the duration of bacterial digestion of the substrates and the type of inhibitors being generated in the biodegradation process. To know the biodegradation pathways is essential for the modelling of anaerobic digestion of different organic wastes.

The duration of biodegradation (or retention times) of the substrates accompanied by biogas production at a volume higher than $1 \%$ of total volume of biogas produced until that moment was 25 days for the dough-and-fat sample, 23 days for the vegetables, and 31 days - the longest - for the sludge from the clarifier (as confirmed by $\mathrm{pH}$ curves prepared on the basis of daily measurements, Fig. 2)

Decomposition of each substrate in the early days of the process was accompanied by a decrease in $\mathrm{pH}$ values (Fig. 2). For the DH+FT mixture, the $\mathrm{pH}$ after 5 days was 7.35 - down from the initial 7.65; for VW the initial $\mathrm{pH}$ of 7.7 was down at 7.12 after 4 days, however, these slight and short-lasting changes are not to be mistaken for acidification of the environment. Problems connected with the undesirable decrease in the $\mathrm{pH}$, resulting in methanogenesis inhibition in the process of anaerobic digestion of various kinds of waste - such as vegetables, fruit, fat - are broadly reported on (Silvestre et al., 2011; Zuo et al., 2013, 2015). According to Mata-Alvarez et al. (2000), the problems are caused by the fast rate of hydrolysis and the accumulation of volatile fatty acids (VFAs).

In the present study, biogas and methane production was stable, as indicated by the profiles of daily output of biogas and methane from fresh matter (Fig. 3) and from volatile solids (Fig. 4). The biogas yield was observed to successively increase daily until its volume was constant. For the fresh matter, the biogas and biomethane yield is clearly the highest for the dough-and-fat mixture. On the other hand, in the case of the volatile solids, yields for the respective samples are more similar, as shown by the curves in Fig. 4. This results obviously from great differences in TS (Table 3). 


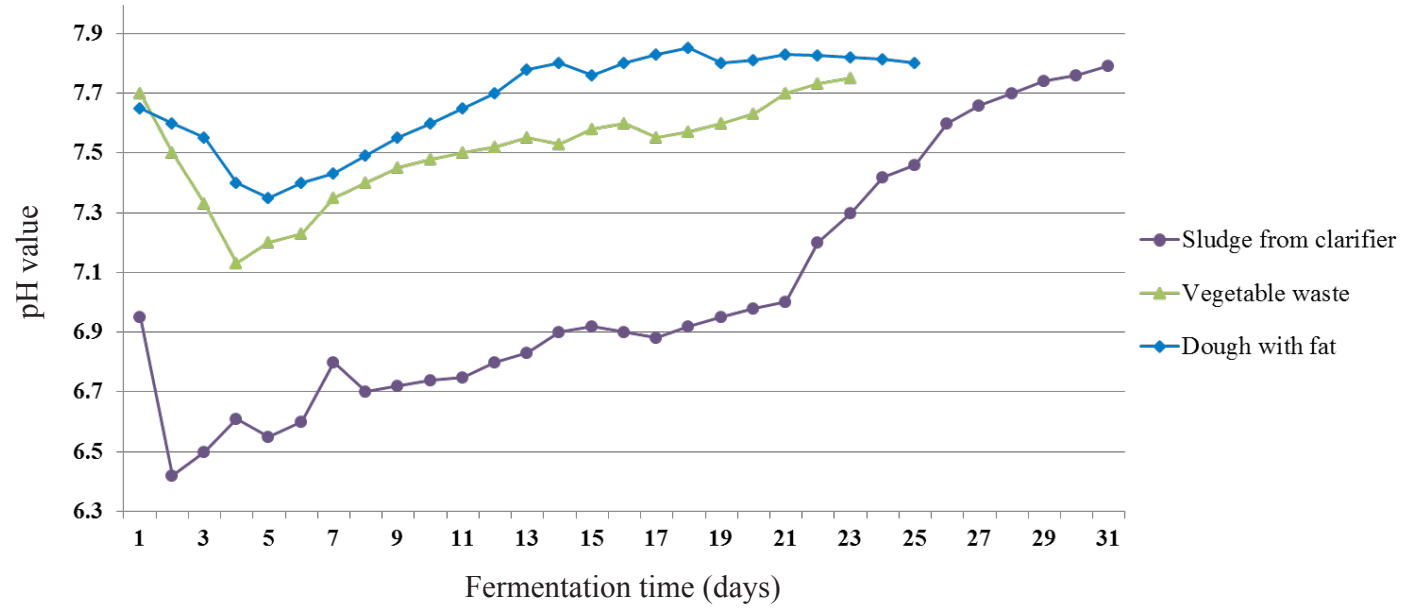

Fig. 2. $\mathrm{pH}$ variation for digested substrates: dough with fat, vegetable waste and sludge from clarifier.

a
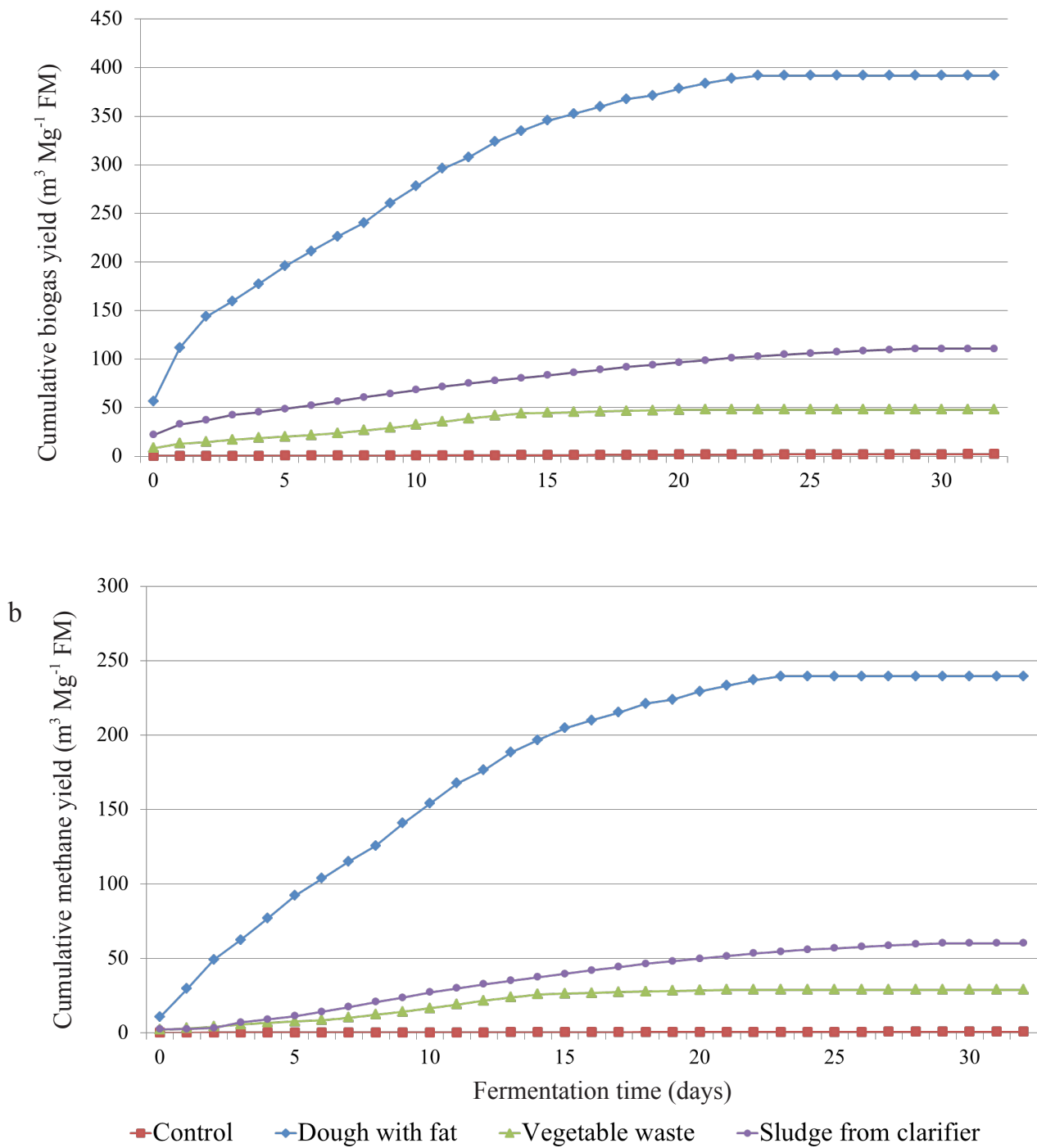

Fig. 3. Cumulative yield of: $a$ - biogas and $b$ - methane from fresh matter of: control (inoculum), dough with fat, vegetable waste, and sludge from clarifier. 
a
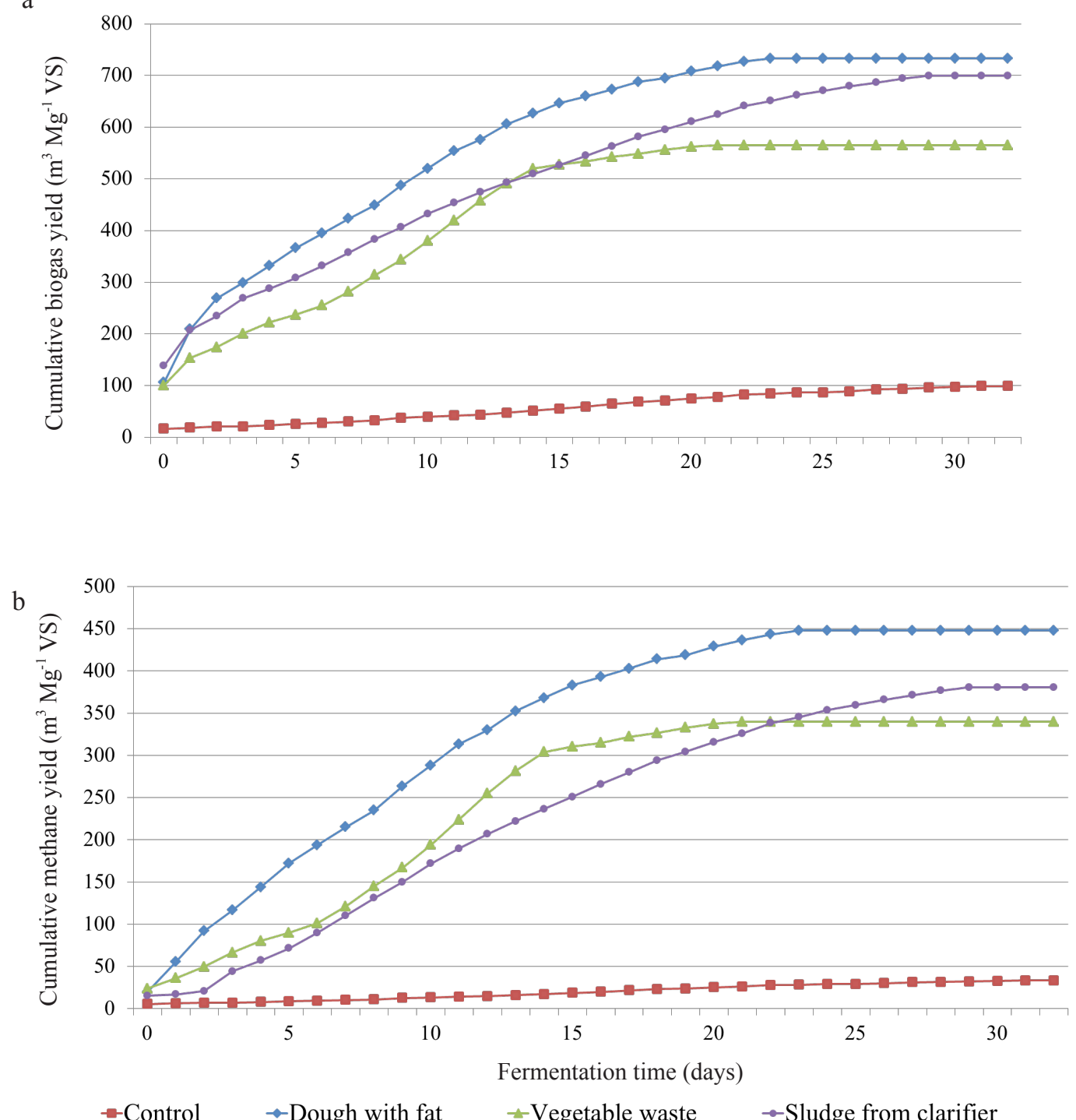

Fig. 4. Cumulative yield of: $a$ - biogas and b - methane from VS of: control (inoculum), dough with fat, vegetable waste, and sludge from clarifier.

The successful anaerobic digestion of the waste types used in this experiment, ie, dough, fat, and vegetables, is attributed to the suitable volumes of substrate and inoculum (Table 1). It was also found that the post-digestion pulp of maize silage and liquid manure (inoculum), is the right one in carrying out anaerobic digestion of vegetable dumplings waste (VDW). Di Maria et al. (2015) also carried out their experiments in stable (neutral) $\mathrm{pH}$ conditions, successfully carrying out AcoD (anaerobic co-digestion) of waste-mixed sludge (WMS) with fruit and vegetable waste (FVW). In turn, Zuo et al. $(2013,2015)$ designed and carried out continuous laboratory-scale experiments on two-stage anaerobic systems treating vegetable waste (VW). To prevent any increase in VFAs and a decrease in $\mathrm{pH}$ which are observed at increasing OLRs, they used acidogenic reactors with a serial methanogenic reactor configuration, as well as recirculation rates (RRs). The problem of anaerobic digestion of fat, during which long chain fatty acids (LCFA) tend to accumulate leading to a inhibited and destabilised process, was solved by Silvestre et al. $(2011,2014)$ who slowly increased the fat waste; this could be a strategy for biomass acclimation to fat-rich substrate. Silvestre et al. (2011) as well as Wan et al. (2011) considered sewage sludge as a good co-substrate for fat.

An analysis of the biogas and methane yields for fresh matter (FM), total solids (TS) and volatile solids (VS) indicates, in each case, that the dough-and-fat (DH+FT) sample provided the highest yield. On the other hand, a more noticeable difference was seen in the values obtained in terms of fresh matter; this was largely due to the high total solids of DH+FT and the much lower TS for SC and VW (Table 3). The dough-and-fat provided $242.89 \mathrm{~m}^{3} \mathrm{Mg}^{-1}$ 
FM methane, sludge from the clarifier did $61.19 \mathrm{~m}^{3} \mathrm{Mg}^{-1}$ FM, while vegetables only $28.72 \mathrm{~m}^{3} \mathrm{Mg}^{-1} \mathrm{FM}$ (Table 2). Performing analyses of biogas yield data for fresh matter is justified, first of all, for economic and logistic reasons, because it relates to the form of substrate which is directly supplied to biogas plants. On the other hand, calculating biogas yields in terms of volatile solids enables a comparison between the results obtained and those expected from the carbon level in a substrate molecule or the chemical reaction stoichiometry. In the present study, the biogas and methane yield in terms of total solids and volatile solids for VW and SC are comparable, and somewhat higher for $\mathrm{DH}+\mathrm{FT}$.

This interpretation of the results is confirmed by way of statistical analysis. The biogas and methane volumes obtained in the experiment are expressed per $\mathrm{Mg}$ of fresh matter, total solids, and volatile solids, so three data sets were analysed. In each data set, the equal-means hypothesis was rejected based on variance analysis. Significantly different means in multiple pair-wise comparisons are denoted by different letters (Table 2). The Tukey test (Cochran and Cox, 1992) indicated significant differences (significance level of 0.05) in biogas and methane yields for all of the samples compared, in terms of fresh matter, and for methane percentage. On the other hand, the difference in the mean volumes of methane in terms of TS and VS for VW and $\mathrm{SC}$ was not significant.

The biogas and biomethane yields for vegetables and fat (present in the sludge from the clarifier, SC) are similar to the results reported by other authors (Silvestre et al., 2011; Wan et al., 2011; Zuo et al., 2013, 2015). A combination of dough and fat $(\mathrm{DH}+\mathrm{FT})$, which was not tested before, has a high biogas production potential, as indicated by the experiments.

\section{CONCLUSIONS}

1. The results have shown that food waste from industrial production of vegetable dumplings: the dough-and-fat, vegetables and sludge from the clarifier, can be disposed of by anaerobic digestion and used in biogas plants.

2. The inoculum in the form of digested pulp of maize silage and liquid manure is suitable for anaerobic digestion of the kinds of waste used.

3. The dough-and-fat mixture is the best source of biogas and methane (fresh matter: $242.89 \mathrm{~m}^{3} \mathrm{Mg}^{-1}$ of methane and $384.38 \mathrm{~m}^{3} \mathrm{Mg}^{-1}$ of biogas; volatile solids: $450.73 \mathrm{~m}^{3} \mathrm{Mg}^{-1}$ of methane and $742.40 \mathrm{~m}^{3} \mathrm{Mg}^{-1}$ of biogas).

4. Yields in terms of total solids and volatile solids for vegetables and sludge from the clarifier were similar: statistical analyses did not show any significant differences between the mean yields of methane (volatile solids: $340.34 \mathrm{~m}^{3} \mathrm{Mg}^{-1}$ for vegetable waste; and $335.83 \mathrm{~m}^{3} \mathrm{Mg}^{-1}$ for sludge from clarifier).
Conflict of interest: The Authors do not declare conflict of interest.

\section{REFERENCES}

Appels L., Assche A.V., Willems K., Degrève J., Impe J.V., and Dewil R., 2011. Peracetic acid oxidation as an alternative pre-treatment for the anaerobic digestion of waste activated sludge. Bioresour. Technol., 102, 4124-4130.

Beck E. and Ziegler P., 1989. Biosynthesis and degradation of starch in higher plants. Annu. Rev. Plant Physiol. Plant Mol. Biol., 40, 95-117.

Belitz H-D., Grosch W., and Schieberle P., 2009. Cereals and cereal products. In: Food chemistry (Eds H.-D. Belitz, W. Grosch, P. Schieberle). Springer, Berlin, Germany.

Brown R.M., J.R., Saxena I.M., and Kudlicka K., 1996. Cellulose biosynthesis in higher plants. Trends Plant Sci., 1, 149-156.

Chen X., Yuan H., Zou D., Liu Y., Zhu B., Chufo A., Jaffar M., and $\mathrm{Li} X ., 2015$. Improving biomethane yield by controlling fermentation type of acidogenic phase in two-phase anaerobic co-digestion of food waste and rice straw. Chem. Eng. J., 273, 254-260.

Chen Y., Cheng J.J., and Creamer K.S., 2008. Inhibition of anaerobic digestion process: A review. Bioresour. Technol., 99, 4044-4064.

Clayden J., Greeves N., Warren S., and Wothers P.D., 2001. Organic chemistry, Oxford University Press Inc., New York, USA.

Cochran W.G. and Cox G.M., 1992. Experimental Designs. Wiley, New York, USA.

Comino E., Riggio V.A., and Rosso M., 2012. Biogas production by anaerobic co-digestion of cattle slurry and cheese whey. Bioresour. Technol., 114, 46-53.

Creighton T.E., 1992. Protein structure and molecular principles. WH Freeman and Company, New York, USA.

Deublein D. and Steinhauser A., 2011. Biogas from waste and renewable resources. WILEY-VCH Verlag $\mathrm{GmbH} \& \mathrm{Co}$ KGaA, Weinheim.

Di Maria F., Sordi A., Cirulli G., and Micale C., 2015. Amount of energy recoverable from an existing sludge digester with the co-digestion with fruit and vegetable waste at reduced retention time. Appl. Energy, 150, 9-14.

Fang C., Boe K., and Angelidaki I., 2011. Anaerobic co-digestion of desugared molasses with cow manure; focusing on sodium and potassium inhibition. Bioresour. Technol., 102, 1005-1011.

Grimberg S.J., Hildebrandt D., Kinnunen M., and Rogers S., 2015. Anaerobic digestion of food waste through the operationofamesophilictwo-phasepilotscaledigester-Assessment of variable loadings on system performance. Bioresour. Technol., 178, 226-229.

Jabeen M., Zeshan M.J., Yousaf S., Haider M.R., and Malik R.N., 2015. High-solids anaerobic co-digestion of food waste and rice husk at different organic loading rates. Int. Biodeter. Biodegr., 102, 149-153.

Kavacik B. and Topaloglu B., 2010. Biogas production from codigestion of a mixture of cheese whey and dairy manure. Biomass Bioenergy, 34, 1321-1329. 
Kondusamy D. and Kalamdhad A.S., 2014. Pre-treatment and anaerobic digestion of food waste for high rate methane production - A review. J. Environ. Chem. Eng., 2, 1821-1830.

Lui B. and Greeley J., 2011. Decomposition pathways of glycerol via $\mathrm{C}-\mathrm{H}, \mathrm{O}-\mathrm{H}$, and $\mathrm{C}-\mathrm{C}$ bond scission on $\mathrm{Pt}(111)$ : a density functional theory study. J. Phys. Chem., 115, 19702-19709.

Mata-Alvarez J., Macé S., and Llabrés P., 2000. Anaerobic digestion of organic solid wastes. An overview of research achievements and perspectives. Bioresour. Technol., 74, 3-16.

Molinuevo-Salces B., Gómez X., Morán A., and García-González M.C., 2013. Anaerobic co-digestion of livestock and vegetable processing wastes: Fibre degradation and digestate stability. Wast. Manag., 33, 1332-1338.

Montanés R., Pérez M., and Solera R., 2014. Anaerobic mesophilic co-digestion of sewage sludge and sugar beet pulp lixiviation in batch reactors: Effect of $\mathrm{pH}$ control. Chem. Eng. J., 255, 492-499.

Neves L., Oliveira R., and Alves M.M., 2006. Anaerobic codigestion of coffee waste and sewage sludge. Wast. Manag., 26, 176-181.

Nghiem L.D., Nguyen T.T., Manassa P., Fitzgerald S.K., Dawson M., and Vierboom S., 2014. Co-digestion of sewage sludge and crude glycerol for on-demand biogas production. Int. Biodeter. Biodegr., 95, 160-166.

Parkin G.F. and Owen W.F., 1986. Fundamentals of anaerobic digestion of wastewater sludges. J. Environ. Eng., 112, 867-920.

Pilarska A., Pilarski K., Dach J., and Witaszek K., 2014. Impact of organic additives on biogas efficiency of sewage sludge. Agric. Eng., 3(151), 139-148.

Pilarska A.A., Pilarski K., Witaszek K., Waliszewska H., Zborowska M., Waliszewska B., Kolasiński M., and Szwarc-Rzepka K., 2016. Treatment of dairy waste by anaerobic digestion with sewage sludge. Ecol. Chem. Eng., 23(1), 99-115.

Pilarski K. and Pilarska A., 2009. Parameters of composting process. Agric. Hortic. Forest Eng., 1, 16-17.

Razaviarani V., Buchanan I.D., Malik S., and Katalambula H., 2013. Pilot-scale anaerobic co-digestion of municipal wastewater sludge with restaurant grease trap waste. J. Environ. Manag., 123, 26-33.

Siddiqui I.R., 1989. Studies on vegetables: fiber content and chemical composition of ethanol - insoluble and - soluble residues. J. Agric. Food Chem., 37, 647-650.

Silvestre G., Illa A.J., Fernández B., and Bonmatí A., 2014. Thermophilic anaerobic co-digestion of sewage sludge with grease waste: Effect of long chain fatty acids in the methane yield and its dewatering properties. Appl. Energy, 117, 87-94.

Silvestre G., Rodríguez-Abalde A., Fernández B., Flotats X., and Bonmatí A., 2011. Biomass adaptation over anaerobic co-digestion of sewage sludge and trapped grease waste. Bioresour. Technol., 102, 6830-6836.

Tawik A. and El-Qelish M., 2012. Continuous hydrogen production from co-digestion of municipal food waste and kitchen wastewater in mesophilic anaerobic baffled reactor. Bioresour. Technol., 114, 270-274.

Wan C., Zhou Q., Fu G., and Li Y., 2011. Semi-continuous anaerobic co-digestion of thickened waste activated sludge and fat, oil and grease. Wast. Manag., 31, 1752-1758.

Waszkielis K.M.,Wronowski R., Chlebus W., Bialobrzewski I., Dach J., Pilarski K., and Janczak D., 2013. The effect of temperature, composition and phase of composting proces on the thermal conductivity of the substrate. Ecol. Eng., 61, 354-357.

Yan Z., Yi-Li Y., Jian-Jun L., Yong-Gui X., Qi-Xin S., and Zhong-Hu H., 2001. The relationship between chinese raw dumpling quality and flour characteristics of Shandong winter wheat cultivars. Agric. Sci. China, 10, 1792-1800.

Zeshan M.J., Yousaf S., Haider M.R., and Malik R.N., 2015. High-solids anaerobic co-digestion of food waste and rice husk at different organic loading rates. Int. Biodeter. Biodegr., 102, 149-153.

Zhan-Jiang P., Jie L., Feng-Mei S., Su W., Ya-Bing G., and Da-Lei Z., 2014. High-solid anaerobic co-digestion of food waste and rice straw for biogas production. J. Northeast Agric. Univ., 21, 61-66.

Zhang C., Su H., Baeyens J., and Tan T., 2014. Reviewing the anaerobic digestion of food waste for biogas production. Renew. Sust. Energ. Rev., 38, 383-392.

Zuo Z., Wu S., Qi X., and Dong R., 2015. Amount of energy recoverable from an existing sludge digester with the codigestion with fruit and vegetable waste at reduced retention time. Appl. Energy, 147, 279-286.

Zuo Z., Wu S., Zhang W., and Dong R., 2013. Effects of organic loading rate and effluent recirculation on the performance of two-stage anaerobic digestion of vegetable waste. Bioresour. Technol., 146, 556-561. 